\title{
KEPEMIMPINAN ORGANISASI PEMBELAJARAN PROGRAM STUDI BAHASA INGGRIS DI STKIP PGRI NGAWI
}

\author{
Nuri Susilowati ${ }^{1,}$ Suyatmini ${ }^{2}$ \\ ${ }^{1), 2)}$ Magister Administrasi Sekolah Pascasarjana UMS
}

\begin{abstract}
The research has five proposed: 1) to describe personal mastery of leadership in english departement at STKIP PGRI Ngawi, 2) to desribe mental methods of leadership in english departement at STKIP PGRI Ngawi, 3) to describe shared vision of leadership in english departement at STKIP PGRI Ngawi, 4) to describe system thinking of leadership in english departement at STKIP PGRI Ngawi. 5) to describe team learning of leadership in english departement at STKIP PGRI Ngawi. The skill is descriptive qualitative research; study case. The source of the data research from the chairman, lecture and students. The result of the research shows that are: 1) personal mastery: a) commitment; personal and a shared commitment, b) creativity, innovative and priorities; good creativity, innovative and priorities. 2) mental methods: a) criticism and suggestions; received and evaluated of the criticism and suggestions, b) Behavior; discipline, responsible and friendly. 3) Shared vision: a) motivation and oppeness; good motivation and slightly open, b) Vision; shared vision. 4) systems thinking has not been so appears. 5) Tim learning: a) position; the position isn't an obstacle to maintain good relations between the others, b) dialogue and discussion; to improve communication.
\end{abstract}

Keywords: leadership, learning organization, education departement

\begin{abstract}
ABSTRAK
Tujuan penelitian ini ada lima: 1) mendiskripsikan penguasaan pribadi kepemimpinan program studi bahasa inggris di STKIP PGRI Ngawi, 2) mendiskripsikan pola berpikir program studi bahasa inggris di STKIP PGRI Ngawi, 3) mendiskripsikan visi bersama kepemimpinan program studi bahasa inggris di STKIP PGRI Ngawi, 4) Mendiskripsikan berpikir sistem kepemimpinan program studi Bahasa Inggris di STKIP PGRI Ngawi, 5) Mendiskripsikan pembelajaran tim kepemimpinan program studi bahasa inggris di STKIP PGRI Ngawi. Jenis penelitian kualitatif studi kasus. Subjek penelitian Kaprodi, Dosen dan Mahasiswa. Teknik pengumpulan data wawancara, observasi dan dokumentasi. Teknik analisis data redukasi, penyajian, dan penarikan kesimpulan. Hasil penelitian menunjukkan bahwa: 1) penguasaan pribadi: a) komitmen; komitmen pribadi dan komitmen bersama, b) kreatifitas, inovatif dan prioritas: kreatifitas, inovatif dan prioritas yang baik. 2) Pola berpikir: a) Kritik dan Saran; menerima dan mengevaluasi setiap kritik dan saran, b) Perilaku; kepribadian
\end{abstract}


yang baik, disiplin, bertanggung-jawab dan ramah. 3) Visi bersama: a) motivasi dan keterbukaan; motivasi yang baik dan sedikit terbuka, b) Visi; visi bersama. 4) sistem berikir belum begitu terlihat. 5) pembelajaran tim: a) posisi; posisi bukan suatu kendala untuk menjaga hubungan baik dengan lingkungannya, b) dialog dan diskusi; meningkatkan komunikasi.

Kata Kunci: kepemimpinan, organisasi pembelajaran, program studi

\section{PENDAHULUAN}

Organisasi mempunyai pengaruh penting bagi lingkungan. Organisasi harus selalu responsif dan adaptif terhadap perkembangan lingkungan yang kompleks, serta selalu tanggap dalam menghadapi persaingan dunia yang terus berkembang. Olehkarena itu dibutuhkan komitmen yang tinggi dalam membangun dan mengembangkan sumber daya yang strategis. Organisasi pembelajaran Learning Organization (LO) merupakan suatu konsep dalam lingkungan organisasi yang dinamis dan LO sebagai strategi dalam kesuksesan organisasi tersebut. Menurut senge (1990: 4) menyatakan bahwa "Belajar organisasi merupakan suatu belajar bersama, dimana manusia belajar secara terus dalam memperluas kapasitas mereka untuk menciptakan hasil yang benar - benar mereka inginkan, tempat menemukan pola-pola baru dan berpikir luas, tempat mengumpulkan aspirasi bersama tersebut dibebaskan dan tempat orang terus-menerus belajar bagaimana belajar bersama”.

Demikian halnya dengan institusi pendidikan saat ini. Lingkungan persaingan baru yang semakin ketat. Dengan adanya persaingan baru tersebut, muncul tantangan baru yang harus dihadapai oleh institusi pendidikan antara lain bertanggung-jawab yang besar terhadap masyarakat, meningkatkan kerjasama serta mengembangkan kualitas mutu yang lebih baik. Olehkarena itu Institusi pendidikan harus melakukan perubahan. Dalam hal ini perubahan berkaitan dengan proses belajar yang efektif.

Institusi Pendidikan pada khususnya di Sekolah Tinggi Keguruan Ilmu Pendidikan program studi bahasa inggris di STKIP PGRI Ngawi adalah merupakan hasil dari suatu proses interaksi yang melibatkan: Yayasan, Ketua, Kaprodi, Dosen, Mahasiswa, buku pegangan kuliah, laboraturium, metodologi pengajaran, peraturan perundang-undangan dibidang pendidikan dan input serta proses kondisi lainnya.

Pencapaian kesuksesan suatu institusi pendidikan tidak hanya merupakan kerja dari Fakultas itu sendiri tetapi adanya kerjasama yang baik dari program studi. Program studi merupakan ujung tombak kesuksesan suatu pendidikan. Secara umum program studi merupakan pelaksana nyata untuk kelangsungan suatu lingkungan akademis yang melibatkan dosen atau pengajar dan juga mahasiswa. Mahasiswa adalah output dari suatu pendidikan yang banyak mendapatkan bimbingan atau pengarahan dari program studi.

Samino (2015: 27) menyatakan bahwa "teori kepemimpinan terkait erat dengan pemimpin leader atau orangnya, sedangkan kepemimpinan leadership adalah ilmu yang mempelajari tentang pemimpin agar dapat berhasil dalam memimpin orang-orang di lingkungannya”. Menurut Yukl (1994: 5) menyatakan bahwa "efektivitas pemimpin adalah sejauh mana unit organisasi dari pemimpin tersebut melaksanakan tugasnya secara berhasil dan mencapai 
tujuan-tujuannya”. Menurut Yukl (1994: 7) menyatakan bahwa "kepemimpinan sebagai sesuatu yang dilakukan seorang pemimpin untuk mempengaruhi sikap dan motivasi dari para pengikut secara individual”.

Demikian halnya STKIP PGRI Ngawi, Program studi dibawah naungan Ketua Program studi. Seorang ketua program studi diharapkan dapat memimpin dan mengelola program studi dengan baik, selain itu juga harus pekaterhadap persaingan yang semakin ketat, serta dibutuhkan kemampuan yang cukup kreatif dalam menghadapi perubahan dengan menggunakan startegi pembelajaran yang tepat. Dan secara umumnya di Lingkungan institusi, Ketua Program studi sebagai penentu awal suatu keputusan yang harus diambil tetapi untuk keputusan-keputusan yang sifatnya besar. Keputusan harus dikoordinasikan dengan pihak tertinggi yang menaungi Fakultas yang bersangkutan dengan baik. Kaprodi harus bekerjasama dengan penguasa tertinggi dari sebuah Instistusi tersebut yaitu Ketua Institusi pendidikan tersebut.

Program studi bahasa inggris di STKIP PGRI Ngawi merupakan salah satu program studi bahasa inggris di Kota Ngawi. Sehingga, keadaan program studi bahasa inggris di STKIP PGRI Ngawi sangat diperhatikan oleh masyarakat di ngawi yaitu mengenai beberapa prestasi yang pernah dicapai dan perkembangan program studi bahasa inggris tersebut. Namun, dua tahun ini mengalami penyusutan peminat dalam program studi bahasa inggris. Selain itu, Kepemimpinan program studi bahasa inggris di STKIP PGRI Ngawi masih belum maksimal. Karena Kaprodi hanya bertugas sebagai pelaksana program studi. Pada umumnya, keberhasilan suatu program studi sangat dipengaruhi oleh kepemimpinan seorang Kaprodi dan tenaga pendidik yang ada di program studi tersebut. Olehkarena itu, organisasi pembelajaran mempunyai manfaat untuk mengetahui keadaan Kaprodi dalam memimpin Program studi Bahasa Inggris di STKIP PGRI Ngawi.

Penelitian ini bertujuan untuk mendiskripsikan Penguasaan Pribadi Personal Mastery kepemimpinan organisasi pembelajaran Program Studi Bahasa Inggris di STKIP PGRI ngawi; (kompetensi dan keahlian: komitmen, kreatifitas dan innovatif, prioritas). Pola Berpikir Kritis Mental Methods kepemimpinan organisasi pembelajaran Program Studi Bahasa Inggris di STKIP PGRI ngawi; (kritik dan saran, perilaku). Visi Bersama Shared Vision kepemimpinan organisasi pembelajaran Program Studi Bahasa Inggris di STKIP PGRI ngawi; (visi, motivasi dan keterbukaan). Berpikir Sistem System thinking kepemimpinan organisasi pembelajaran Program Studi Bahasa Inggris di STKIP PGRI ngawi; (keberhasilan kerja dan mengolah konflik). Pembelajaran Tim Team Learning kepemimpinan organisasi pembelajaran Program Studi Bahasa Inggris di STKIP PGRI ngawi; (position, dialog dan diskusi).

\section{METODE}

Jenis penelitian ini adalah penelitian kualitatif. Sugiyono (2013: 1-2) menyatakan bahwa "Metode penelitian Kualitatif ini sering disebut penelitian naturalistik karena penelitiannya dilakukan pada kondisi yang alamiah Natural Setting. Desain yang digunakan dalam penelitian ini adalah studi kasus. Lokasi penelitian adalah suatu institusi pendidikan di jawa timur. Institusi pendidikan di STKIP PGRI Ngawi di Jawa Timur. Penulis memilih program studi Bahasa Inggris sebagai bahan penelitian. Penelitian ini dilaksanakan selama 6 bulan, yaitu bulan Maret 2015 sampai September 2015.

Teknik pengumpulan data melalui wawancara, observasi dan dokumentasi. Teknik 
analisis data yang digunakan adalah model alur flow model Miles dan Huberman, menurut Miles dan Huberman dalam Sugiyono (2013: 91) mengemukakan "aktifitas dalam analisis data kualitatif dilakukan secara interaktif dan berlangsung secara terus menerus sampai tuntas, sehingga datanya sudah jenuh”. Teknik analisis data dengan redukasi, penyajian data dan penarikan kesimpulan. Kemudian, keabsahan data dalam kaitanya dengan kredibilitas penelitian yang dilakukan, maka peneliti menggunakan teknik trianggulasi data, karena dengan keabsahan data merupakan langkah awal dari kebenaran analisis data. Trianggulasi data Sugiyono (2013: 117) menyatakan bahwa "Penelitian kualitatif, temuan atau data dapat dinyatakan valid apabilla tidak ada perbedaan antara yang dilaporkan peneliti dengan apa yang sesungguhnya terjadi pada obyek yang diteliti”.

Dalam penelitian ini, untuk menguji keabsahan data yang diperoleh menggunakan trianggulasi sumber, trianggulasi metode dan trianggulasi waktu. Masing- masing diuraikan sebagai berikut; 1) Trianggulasi sumber digunakan untuk menguji keabsahan data dengan pengecekan data yang telah diperoleh melalui beberapa sumber, peneliti membandingkan data yang sama tentang kepemimpinan organisasi pembelajaran program studi bahasa inggris dari tiga informan atau lebih, yakni membandingkan data yang diperoleh dari Ketua program studi, Dosen dan Mahasiswa. 2) Trianggulasi metode yang digunakan untuk menguji keabsahan data, peneliti membandingkan data tentang kepemimpinan organisasi pembelajaran program studi dari informan yang diperoleh melalui wawancara dan observasi. 3) Trianggulasi waktu digunakan untuk keabsahan data, peneliti melakukan pengamatan, wawancara dalam waktu dan situasi yang berbeda. Peneliti menggunakan wawancara di siang dan sore hari saat narasumber diluar jam kerja sehingga tidak menggangu aktifitasnya.

\section{HASIL DAN PEMBAHASAN}

\section{Penguasaan Pribadi Personal Mastery Kepemimpinan Program Studi Bahasa Ing- gris di STKIP PGRI Ngawi.}

Komitmen merupakan suatu penguasaan pribadi yang harus dimiliki oleh Kaprodi dalam kepemimpinannya. Seorang pemimpin memerlukan komitmen tinggi dalam suatu tanggungjawabnya. Keberhasilam sebuah institusi sangat dipengaruhi oleh kekuatan komitmen pribadi personal dan bersama. Selain itu Kaprodi juga harus dapat menumbuhkan komitmen bagi Sekretaris, Dosen dan Mahasiswa. Komitmen Kaprodi Bapak Zaenal Abidin sangat berpengaruh pada kepemimpinannya untuk belajar secara terus-menerus. Kemajuan Institusi pendidikan memerlukan dukungan dari program studi. Hal ini sesuai dengan penelitian Absah (2008) karakteristik penting dari organisasi akan kapasitas mereka untuk belajar dari pengalamaan dan beradaptasi terus menerus untuk perubahan kondisi eksternal. Komitmen merupakan suatu karakteristik penting untuk dapat meningkatkan kualitas diri untuk terus belajar. Olehkarena itu Kaprodi harus dapat membawa sekretaris, dosen, mahasiswa untuk dapat menumbuhkan komitmen bersama sesuai standar yang diharapkan.

Kreatifitas dan innovatif Kaprodi itu bersifat alami. Ketika seorang pemimpin mengalami suatu kendala, maka pola pikir akan terfokus dan berusaha mencari solusi. Kaprodi memerlukan kemampuan kreatifitas dan innovatif yang tinggi. Kreatifitas tinggi yang selalu innovatif dalam menciptakan ide - ide baru. Sehingga muncul ide-ide kreatif yang dapat 
menciptakan organisasi pembelajaran learning organization (LO) dan pengembangan diri bagi mahasiswa. Contohnya, kegiatan pengabdian masyarakat dan KKN merupakan kegiatan untuk mencari pengalaman ilmu pengetahuan. HMJ merupakan sarana bagi mahasiswa dalam mengembangkan kreatifitasnya. Hal ini sesuai dengan hasil penelitian oleh Gilaninia dkk (2013) hasil penelitiannya untuk melaksanakan ide-ide, organisasi menciptakan dasar perubahan dalam metode manajemen dan pembelajaran mereka yang selalu siap untuk belajar dan ide-ide baru untuk beradaptasi dengan perubahan. Olehkarena itu, Kreatifitas dan Innovatif Kaprodi harus lebih ditingkatkan karena dapat menciptakan perubahan dalam metode manajemen dan pembelajaran untuk dapat belajar dari ide-ide baru menuju perubahan lebih baik.

Prioritas merupakan suatu prinsip seseorang dalam melakukan tanggung-jawabnya sesuai dengan batas waktu yang telah ditentukan. Kaprodi tidak boleh sungkan untuk mengingatkan dosen agar segera menyelesaikan tugas dengan maksimal dan batas waktu yang telah ditentukan. Ketika dihadapkan dengan tugas yang begitu banyak dengan batas waktu yang beriringan, Kaprodi harus dapat membuat prioritas yang baik. Hal ini sesuai dengan penelitian oleh Searby dan Shaddix (2008). Hasil penelitian menunjukkan bahwa program kepemimpinan guru yang dikembangkan oleh sekolah Mountain Brooks diharapkan menjadi kebiasaan para guru dan staff dalam pembelajaran maupun pembelajaran di kelas terkait dengan profesionalitasnya sebagai kepala sekolah atau seorang pengajar (pendidik). Kebiasaan menciptakan prioritas kerja yang diterapkan oleh seorang Kaprodi secara profesional, maka akan menjadi suatu budaya yang dapat dijadikan sebagai cerminan bagi dosen dan mahasiswa di sebuah institusi pendidikan.

\section{Pola Berpikir Kritis Mental Methods Kepemimpinan Program Studi Bahasa Ing- gris di STKIP PGRI Ngawi.}

Kritik dan saran sebagai proses perbaikan dan kemajuan diri untuk menjadi lebih baik. Segala kritik dan saran akan dipelajari dan melakukan intropeksi diri untuk lebih baik lagi. Dosen memberikan kritik dan saran untuk Kaprodi, dan Kaprodi memberikan kritik dan saran untuk dosen agar motivasi kerja bersama untuk lebih ditingkatkan. Kaprodi segera menindaklanjutinya, karena itu berpengaruh pada pelayanan program studi. Hal ini sesuai dengan penelitian oleh Purhaghshenas dkk (2012) Penelitian ini menemukan sifat dimana kita hidup ada banyak perbedaan di antara masa lalu dan organisasi saat ini dan yang berkaitan dengan topik ini, pihak berwenang di bidang manajemen mengatakan: saat ini kesepakatan manajer dengan organisasi-organisasi yang tidak mirip dengan organisasi di masa lalu. Salah satu fitur dasar organisasi baru pembentukan mereka berdasarkan pembelajaran. Oleh karena itu Kaprodi terus-menerus belajar dalam manajemennya, dosen dapat meningkatkan kualitas mengajarnya dan mahasiswa mendapatkan keterampilan baru untuk dapat meningkatkan kualitas dirinya.

Perilaku kaprodi sangat berpengaruh pada kepemimpinannya, seperti sikap kejujuran dan tanggug-jawab merupakan suatu prinsip penting dalam melakukan tugas sebagai seoarang pemimpin. Sikap ramah merupakan perilaku terpuji dan santun. Sikap Kaprodi sangat berpengaruh pada kepemimpinannya. Olehkarena itu, Sikap Kaprodi dan Dosen 
sangat berpengaruh pada keberhasilan mahasiswanya. Mahasiswa harus selalu mendapatkan dukungan dari pihak institusi termasuk Kaprodi dan Dosen. Kaprodi dan Dosen harus mampu memenuhi kebutuhan mahasiswa yang dapat mendukungnya. Hal ini sesuai dengan hasil penelitian oleh Peleg, Selfi (2012). Hasil penelitiannya menunjukkan bahwa seorang pemimpin pendidikan yang dinamis bertanggung-jawab untuk lebih dari memenuhi standar yang diharapkan. Olehkarena itu, Kaprodi bertanggung-jawab untuk dapat membawa sekretaris, dosen, mahasiswa untuk dapat menumbuhkan rasa tanggung-jawab pada tugasnya masing-masing, sehingga dapat memperoleh standar yang diharapkan.

\section{Visi Bersama Shared Vision Kepemimpinan Program Studi Bahasa Inggris di ST- KIP PGRI Ngawi.}

Motivasi dan keterbukaan Kaprodi mempunyai pengaruh dalam kepemimpinannya. Seorang pemimpin memerlukan motivasi sebagai suatu dorongan untuk lebih semangat dan optimis dalam menjalani aktifitasnya agar tujuan bersama dapat tercapai. Peran Kaprodi adalah sebagai seorang pemimpin, yang juga mahir dalam manajemennya. Manajemen diri, orang lain dan program studi. Ketiga manajemen itu merupakan tanggung-jawab bagi Kaprodi yang harus dikembangkan. Hal ini sesuai dengan penelitian Brahmasari dkk (2008) motivasi kerja dapat tidak terkait langsung dengan kinerja perusahaan jika tidak terhubung dengan kepuasan kerja karyawan yang variable dan pimpinan yang berhubungan negatif dengan pekerjaan kepuasan karyawan. Motivasi dan keterbukaan merupakan suatu budaya organisasi yang dapat menciptakan kepuasan kerja. Oleh karena itu, Kaprodi harus mempunyai motivasi kerja dan keterbukaan yang positif, karena dapat meningkatkan kepuasan kerja.

Visi merupakan suatu hal penting yang harus dimiliki oleh suatu lembaga atau institusi pendidikan sebagai sebuah harapan dimasa depan. Sedangkan misi adalah tindakan yang dilakukan untuk mencapai harapan tersebut. Seorang Kaprodi harus mempunyai visi masa depan, dan memprediksi untuk memahami perubahan hasil ide yang dirancangkan dalam organisasi. Program studi khususnya Kaprodi harus memahami apa yang menjadi keinginan mahasiswanya. Karena kenyamanan merupakan suatu pelayanan penting dalam sebuah institusi. Visi dan misi yang dimiliki STKIP PGRI Ngawi dirumuskan sebagai berikut: Visi STKIP PGRI Nagwi sebagai lembaga perguruan bidang pendidikan yang berkualitas, profesional, unggul dan kompetitif. Misi STKIP PGRI Ngawi adalah 1) Menyelenggarakan pendidikan tinggi untuk menyiapkan tenaga pendidik profesioanl yang berdaya saing global, 2) mengembangkan kegiatan penelitian untuk mengkaji dan mengembangkan ilmu pengetahuan, teknologi, dan seni. 3) Mengembangkan pengabdian pada masyarakat yang mendorong pengembangan potensi sumberdaya alam dan manusia baik secara individu maupun bersama-sama untuk mewujudkan masyarakat belajar dalam karangka pembangunan nasional. Hal ini sesuai dengan hasil penelitian Nakpodia (2009) hasil penelitiannya, berkomitmen untuk menciptakan pembelajaran yang berkelanjutan peluang, mendorong kolaborasi dan pembelajaran tim, membangun sistem untuk menangkap dan berbagi belajar, dan menghubungkan organisasi universitas untuk lingkungannya. Olehkarena itu, Kaprodi harus mampu untuk menciptakan pembelajaran yang dapat membangun pengembangan potensi sumberdaya secara individu dan bersama-sama. 


\section{Berpikir Sistem System Thinking Kepemimpinan Program Studi Bahasa Inggris di STKIP PGRI Ngawi.}

Keberhasilan kerja program studi merupakan suatu harapan bersama. Sebagai seorang pemimpin tertinggi, mempunyai visi yang belum dimiliki oleh anggotanya. Olehkarena itu, institusi memfasilitasi dan mengatur agar visi lebih sinergi. Keberhasilan Kaprodi tidak hanya terlihat dalam karya yang dihasilkan, namun membangun kebiasaan baik juga merupakan suatu keberhasilan Kaprodi, karena dapat menciptakan budaya belajar. Hal ini sesuai dengan hasil penelitian Brahmasari dkk (2008) Hasil penelitian tersebut telah dibuktikan pekerjaan yang motivasi, kepemimpinan, dan budaya organisasi secara signifikan berhubungan dengan kepuasan kerja karyawan. Olehkarena itu, Kaprodi harus dapat berkomitmen untuk dapat menciptakan keberhasilan program studi, dengan cara melakukan pembelajaran terusmenerus dan menghubungkan organisasi institusi untuk lingkungannya yang lebih baik lagi.

Konflik merupakan suatu kejadian yang natural, sehingga perlu pemahaman yang tepat dalam mengolah konflik. Program studi bahasa inggris di STKIP PGRI merupakan salah satu jurusan bahasa inggris di kota ngawi. Dari hasil penelitian, Peminat masyarakat untuk program studi bahasa inggris di STKIP PGRI Ngawi mengalami penurunan. Penurunan peminat jurusan bahasa inggris merupakan suatu konflik yang memicu keraguan masyarakat untuk menlanjutkan pendidikan di suatu perguruan tinggi tersebut. Hal ini sesuai dengan hasil penelitian Jenny Lagsten dan Goran Goldkuhl (2009) Hasil dari evaluasi adalah sebagai pengetahuan yang diterapkan untuk digunakan untuk merencanakan dan melaksanakan tindakan untuk individu di dalam organisasi. Institusi, Kaprodi dan Dosen harus bekerjasama untuk mengembalikan kepercayaan masyarakat. Jurusan yang terakreditasi baik akan mempunyai nilai jual yang tinggi yang dapat melahirkan lulusan yang baik pula. Olehkarena itu institusi dan program studi harus lebih meningkatkan sistem manajemen kerja yang labih baik lagi.

\section{Pembelajaran Tim Team Learning Kepemimpinan Program Studi Bahasa Inggris di STKIP PGRI Ngawi.}

Position merupakan suatu jabatan posisi yang mempunyai peran penting dalam kepemimpinanya. Kaprodi mempunyai posisi penting dalam keberhasilan program studinya. Namun, posisi bukanlah suatu kendala untuk menjaga hubungan baik dengan tim kerja. Sikap Kaprodi yang sabar dan ramah mempunyai dampak positif dalam kepemimpinannya. Hal ini sesuai dengan hasil penelitian Ayiro Greenle (2007) hasil penelitiannya kemampuan kepemimpinan termasukgaya kepemimpinan dalampendidikan yang mampu mengadaptasikan berbagai gaya kepemimpinan dalam lingkungan yang cocok, memiliki kemampuan dan prespektif kerja yang lebih luas dan tidak terbatas pada jabatan pokoknya, mampu bekerja dengan orang lain dalam tim virtual dan membimbing kelompok yang berbeda untuk menyampaikan tujuan pendidikan. Olehkarena itu, position Kaprodi bukan suatu kendala untuk menjaga hubungan baik dengan dosen dan mahasiswanya, namun menerapkan ramah dan sabar jauh lebih penting dalam pelayanannya.

Dialog dan diskusi merupakan interaksi dua orang atau lebih, ini merupakan proses dimana Kaprodi dan Dosen melakukan dialog dan diskusi melalui kegiatan seminar atau workshop. Seminar/Workshop merupakan kegiatan yang dapat meningkatkan kemampuan 
untuk berdialog dan berdiskusi. Melalui kegiatan itu Kaprodi dan dosen tidak saling mematikan pendapat, Kaprodi memberikan kesempatan kepada dosen untuk mendengar dan berbicara. Ketika proses belajar mengajar di kelas, Kaprodi (dosen) juga harus mampu menciptakan keaktifan dengan cara dialog dan diskusi, sesuai dengan tema materi pembelajaran yang dapat membangun wawasan mahasiswa untuk lebih aktif dan kritis. Hal ini sesuai dengan hasil penelitian Salman dkk (2012) hasil penelitiannya perubahan ini telah mengubah cara hidup, komunikasi, dan bisnis dan bahkan pola pembelajaran. Olehkarena itu, Kaprodi harus dapat menciptakan kegiatan dialog dan diskusi, melalui kegiatan ini dapat mengubah cara hidup dan meningkatkan komunikasi serta pola pembelajaran yang positif.

\section{SIMPULAN}

Penguasaan pribadi, Kaprodi harus dapat menumbuhkan komitmen, kreatifitas dan innovatif serta prioritas kerja didalam program studinya. Pola berpikir Kaprodi sangat dibutuhkan dalam proses organisasi pembelajaran. Perilaku dan visi merupakan bagian dari pola berpikir. Olehkaren itu sikap kejujuran dan tanggung-jawab merupakan suatu prinsip penting dalam melakukan tugas sebagai seoarang pemimpin serta visi dan misi program studi harus sejalan dengan visi dan misi institusi sebagai tujuan bersama. Sistem berpikir, belum begitu terlihat, konsep yang mendasar dan kerjasama yang kuat antara institusi dan program studi untuk terus meningkatkan sistem manajemen dan siap untuk bersaing. Pembelajaran tim Kaprodi, posisi bukan suatu kendala untuk menjaga hubungan baik dengan lingkunngannya. Oleh karena itu, Kaprodi dan Dosen melakukan dialog dan diskusi untuk meningkatkan komunikasi.

Lima komponen organisasi pembelajaran diatas dapat disimpulkan bahwa, Institusi pendidikan yang menerapkan organisasi pembelajaran, akan berusaha untuk meningkatkan kualitas mereka. Kaprodi dan Dosen harus bekerjasama untuk mengembalikan kepercayaan masyarakat. Jurusan yang terakreditasi baik akan mempunyai nilai jual yang tinggi yang dapat melahirkan lulusan yang baik pula. Olehkarena itu, dalam lingkup program studi dengan berpikir sistem Kaprodi dapat mengevaluasi kekurangan yang ada dalam program studi dan kemudian akan dikomunikasikan dengan pihak institusi agar dapat dilakukan tindakan selanjutnya. Sehingga, institusi dan program studi bekerjasama untuk lebih meningkatkan sistem manajemen kerja yang labih baik lagi.

\section{DAFTAR PUSTAKA}

Abbasi, Taqipour, dan Farhadian. 2012. Learning organization discipline in

irianian higher education system. Iran: WJEIS. Journal of educational and intstructional studies in the world,. May 2, Vol: 2 Article: 08 ISSN: 2146-7463.

Absah. 2008. Pembelajaran Organisasi: Strategi Membangun kekuatan perguruan tinggi. Journal Manajemen bisnis, Vol.1, No. 01, 33-41

Ayiro laban p. Sang james k. Arap, 2010 . education leadership in a globalized

economy: a kenyan perspective. Journal of science and technology education research vol.1 (4) september 2010 p. 62-72

Lunenburg. 2011. Sytems Thinking and the Learning Organization: The Path to School Improvement. Sam Houston State University. Vol. 2, No. 1. 
Moleong, Lexy J. 2013. Metode Penelitian Kualitatif. Edisi Revisi. Bandung: PT Remaja Rosdyakarya.

Nakopedia. 2009. The concept of the university as learning organization: its

fuctions, techniques and possible ways of making it effective. Journal of public administration and policy research Vol. 1 (5) pp. 079-083

Peleg selfi, 2012. The role of leadership in the education system. Education Journal, vol. 1 No. 1, 2012, PP. 5-8

Purhaghshenas dan Esmatnia. 2012. Learning Organizations. Iran: IJCRB. November 2012 Vol 4, No 7

Senge, Peter M. 1990. The Fifth Discipline. The Art And Practice Of The Learning Organization. New York: Doubleday Currency.

Samino. 2015. Kepemimpinan Pendidikan. Kartasura: Fairus media

Sugiyono. 2007. Metodologi Penelitian Pendidikan Pendekatan Kuantitatif, Kualitatif \& RD. Bandung: Alfabeta

Sutama. 2012. Metode Penelitian Pendidikan kuantitatif, kualitatif, PTK, Research and Development. Fairuz Media: Surakarta.

Yukl, G. 2010. Leadership in Organization. Seventeenth Edition. Upper Saddler River, New Jersey: Person. 